Otentik's: Jurnal Hukum Kenotariatan (Vol 2, No. 2, Juli 2020)

p-ISSN 2655-5131 e-ISSN 2685-3612

\title{
KAJIAN TANGGUNG JAWAB SEKUTU KOMANDITER DALAM PELUNASAN HUTANG PERUSAHAAN MELALUI KEPAILITAN (Studi Kasus Putusan Nomor: 07/Pdt.Sus-Pailit/2015/ PN Niaga. Mdn)
}

\author{
PUTRA MA ALHAIRI \\ Alkhoiri75@yahoo.com
}

\begin{abstract}
Abstrak
Kepailitan merupakan suatu keadaan yang dapat terjadi kepada perorangan dan badan usaha. Persekutuan komanditer sebagai badan usaha juga dapat dinyatakan pailit melalui para sekutunya yaitu komplementer dan komanditer. Terhadap tanggungjawab kerugian yang dialami oleh persekutuan, sekutu komplementer bertanggungjawab penuh sedangkan sekutu komanditer hanya sebatas pemasukannya, namun bagaimanakah bentuk tanggungjawab mereka dalam keadaan pailit, maka hal ini bagi penulis dipandang perlu untuk dianalisis lebih mendalam. Penelitian ini dibatasi dengan dua instrument pertanyaan yaitu bagaimanakah kedudukan hukum sekutu komanditer dalam perusahaan berbentuk persekutuan komanditer, kemudian apakah arti dan akbiat hukumnya bila sekutu komanditer ikut ditetapkan sebagai debitor pailit dalam kepailitan persekutuan komanditer. Jenis penelitian yang penulis gunakan ialah deskriptif analitis dengan pendekatan secara normatif dan melakukan analisis data secara kualitatif. Hasil penelitian penulis yaitu sekutu komanditer tersebut memiliki kedudukan hukum sebagai sekutu pelepas uang dan ia tidak boleh mewakili perseroan bertindak atas nama persekutuan. Selanjutnya arti kepailitan bagi sekutu komanditer yaitu secara normative ia tidak bisa dinyatakan ikut terlibat dalam kepailitan tersebut, dan akbat yang timbul jika ia ditetapkan sebagai debitor pailit tersebut ialah ia harus memikul beban tanggungjawab yang sama dengan sekutu komplementer yaitu bertanggungjawab penuh hingga keharta pribadinya. Dari penelitian ini penulis menyimpulkan bahwa kedudukan hukum sekutu komanditer hanyalah sebagai sekutu pasif dan tidak bisa bertindak atas nama persekutuan dan kepailitan dapat terjadi pada sekutu komanditer dan ia akan bertanggungjawab sampai keharta pribadinya jika terbukti ikut bertindak dalam mengurus persekutuan komanditer.
\end{abstract}

Kata Kunci: Sekutu Komanditer, Pelunasan Hutang, Kepailitan.

\begin{abstract}
Bankruptcy is a condition that can occur to individuals and business entities. The communal alliance as a business entity can also be declared bankrupt through its allies, namely complementary and cooperative. With regard to the responsibility of losses suffered by the alliance, complementary allies are fully responsible while the allied commanders are limited to their income, but how are their responsibilities bankrupt? deemed necessary to be analyzed more deeply. This research is limited to two instrument questions, namely how is the legal position of a conventional ally in a company in the form of a communal alliance, then whether the meaning and legal consequences if the
\end{abstract}


allied commanders are determined to be bankrupt debtors in the bankruptcy of the communal alliance. The type of research that I use is analytical descriptive with a normative approach and qualitative data analysis. The results of the research of the author, that the allied commanders have a legal position as money-releasing allies and he may not represent the company acting on behalf of the alliance. Furthermore, the meaning of bankruptcy for the partner allies, namely normatively, he cannot be declared to be involved in the bankruptcy, and the consequence that arises if he is determined as the bankrupt debtor is that he must shoulder the same responsibility as the complementary ally, which is fully responsible for his personal assets. From this study the authors conclude that the legal position of the commandant allies is only as a passive ally and cannot act on behalf of the alliance and bankruptcy can occur to the allied commanders and he will be responsible to his personal status if proven to act in the management of the communal alliance.

Keywords: Allied Commanditaries, Repayment of Debt, Bankruptcy.

\section{PENDAHULUAN}

Secara garis besar kepailitan merupakan suatu lembaga baru yang tercipta dalam perkembangan bisnis di Indonesia terutama pasca reformasi. Bagi sebagian masyarakat, kepailitan hanya mungkin terjadi pada perusahaan atau industri skala besar saja dan mereka seakan melupakan bahwa dirinya sendiri merupakan subjek hukum yang dapat dinyatakan pailit ${ }^{1}$. Padahal, kepailitan merupakan salah satu sarana yang dapat dipakai oleh kreditor untuk mendapatkan pelunasan piutangnya dari debitor, baik itu debitor perorangan maupun badan hukum. Syarat-syarat dan prosedur permohonan pernyataan pailit serta jangka waktu yang lebih pasti dalam prosesnya, menjadi salah satu alasan kreditor menggunakan sarana kepailitan ini dalam mendapatkan pelunasan piutangnya.

Sejalan dengan pesatnya perkembangan dunia usaha, seorang pengusaha tidak lagi hanya menjalankan usahanya sendiri, melainkan mereka telah secara Bersama-sama membentuk persekutuan ataupun perseroan ${ }^{2}$ atau suatu perusahaan. Pasal 1 Huruf B Undang-Undang Nomor 3 Tahun 1983 Tentang Wajib Daftar Perusahaan menjelaskan bahwa perusahaan merupakan setiap bentuk usaha yang menjalankan setiap jenis usaha yang bersifat tetap dan terus-menerus dan yang didirikan, bekerja serta berkedudukan dalam wilayah Negara Republik Indonesia, untuk tujuan memperoleh keuntungan dan atau laba.

\footnotetext{
${ }^{1}$ Aria Sayudi, Eryanto Nugroho dan Herni S, Nurbayani, Analisis Hukum Kepailitan Indonesia, Kepailitan Dinegeri Pailit, (Jakarta: PSHK), 2004, hlm 7.

${ }^{2}$ R. Soekardono, Hukum Dagang Indonesia, (Jakarta: Rajawali Press), 1981, hlm 32.
} 
Perusahaan yang terwujud dalam bentuk badan usaha ini bila ditinjau dari status yuridisnya dapat dibedakan menjadi 2 (dua) golongan besar, yaitu: ${ }^{3}$

1. Badan usaha yang termasuk badan hukum, seperti perseroan terbatas, yayasan atau koperasi.

2. Badan usaha yang tidak termasuk badan hukum, seperti perusahaan perorangan, persekutuan perdata, persekutuan firma, atau persekutuan komanditer.

H.M.N.Purwosujtipto menegaskan bahwa agar suatu badan dapat dinamakan badan hukum harus terpenuhi syarat-syarat sebagai berikut: ${ }^{4}$

1. Adanya harta kekayaan (hak-hak) dengan tujuan tertentu, terpisah dari kekayaan pribadi para sekutu badan itu.

2. Kepentingan yang menjadi tujuan adalah kepentingan bersama yang bersifat abadi.

3. Adanya beberapa orang sebagai pengurus dibadan itu.

Kemudian jika melihat salah satu badan usaha bukan badan hukum, H.M.N.Purwosutjipto mengatakan bahwa persekutuan komanditer telah memenuhi unsurunsur materil ini, hanya unsur formil sebagai badan hukum saja yang belum terpenuhi, yakni adanya pengesahan dari pemerintah. Pendapat ini turut didukung oleh Chaidir Ali, yang pada pokonya menyatakan bahwa untuk mendirikan suatu badan hukum mutlak diperlukan adanya pengesahan dari pemerintah. ${ }^{5}$

Pemerintah dalam rancangan undang-undang tentang badan usaha perseroangan dan badan hukum menerangkan persekutuan komanditer merupakan badan usaha bukan badan hukum diartikan sebagai bentuk usaha bukan badan hukum, didirikan berdasarkan perjanjian persekutuan antara dua orang atau lebih yang mengaitkan diri untuk bekerja sama secara terus-menerus dengan memberikan pemasukan berupa uang, barang, tenaga, keahlian dan atau klien/ pelanggan guna diusahakan bersama, mempunyai nama dan kedudukan tetap dengan tujuan mencari dan membagi bersama keuntungan yang diperoleh.

Walaupun Persekutuan Komanditer bukanlah merupakan badan usaha berbentuk badan hukum, masih banyak kalangan pengusaha yang menggunakan bentuk usaha ini, terutama kalangan pengusahan industri kecil ataupun industri rumah tangga. Kitab undang-undang Hukum Dagang (KUHD) mengatur tentang persekutuan komanditer dalam 3 (tiga) pasal saja, yakni pasal 19, pasal 20 dan pasal 21. Pasal-pasal ini berada

\footnotetext{
${ }^{3}$ Chidir Ali, Badan Hukum, (Bandung: Alumni), 1991, hlm, 108.

${ }^{4}$ H.M.N. Purwosutjiopto, Pengertian Pokok Hukum Dagang Indonesia 2, Bentuk-Bentuk Perusahaan, (Jakarta: Djambatan) 2007, hlm 66.

${ }^{5}$ Chidir Ali, Op.Cit., hlm 84.
} 
diantara pasal-pasal lainnya yang mengatur tentang persekutuan firma pasal 16 sampai dengan pasal 35 KUHD) Hal ini dikarenakan persekutuan komanditer merupakan bentuk khsusus dari persekutuan firma, kekhususan mana terletak pada keberadaan sekutu komanditer yang tidak pada persekutuan firma. ${ }^{6}$ Selanjutnya juga terdapat beberapa pasal dalam Kitab Undang-Undang Hukum Perdata yang mengatur tentang persekutuan ini.

Sekutu komanditer merupakan sekutu yang hanya menyerahkan uang atau barang yang diperlukan untuk menjalankan perusahaan kepada satu atau lebih sekutu lainnya yang melakukan pengurusan terhadap perusahaan tersebut. Sekutu yang melakukan pengurusan perusahaan inilah yang berhubungan dengan pihak ketiga, sedangkan sekutu komanditer tidak diketahui oleh pihak ketiga.

Dengan adanya pemasukan uang, barang ataupun tenaga oleh para sekutu kedalam persekutuan komanditer, maka dapatlah dikatakan bahwa persekutuan komanditer mempunyai kekayaan tersendiri yang terpisah dari kekayaan para sekutunya. Kekayaan ini merupakan suatu kekayaan bersama yang dimiliki bersama oleh para sekutu dan tidak dapat dipergunakan lagi secara pribadi atau untuk kepentingannya sendiri, melainkan harus digunakan untuk kepentingan bersama persekutuan komanditer. ${ }^{7}$

Dengan menjalankan usahanya, persekutuan komanditer yang dalam hal ini diwakili oleh sekutu pengurus/ sekutu komplementer akan melakukan perikatan-perikatan dengan pihak ketiga. Perikatan-perikatan mana memiliki nilai ekonomis sekutu pengurus berkewajiban agar persekutuan komanditer dapat memenuhi kewajibannya sebgaimana termuat dalam setiap perikatan yang dibuatnya. Namun tidak semua badan usaha termasuk persekutuan komanditer dapat memenuhi kewajibannya dalam perikatan tersebut. Ada kalanya persekutuan komanditer dihadapkan pada suatu keadaan tidak mampu lagi melaksanakan hutangnya/ kewajibannya yang dapat dinilai secara ekonomis tersebut (insolvable). Bila keadaan ini benar-benar terjadi pihak yang berkepentingan atau seorang kreditur.

Undang-Undang Nomor 37 Tahun 2004 Tentang Kepailitan Dan Penundaan Kewajiban Pembayaran Utang telah mengatur syarat debitor yang mempunyai dua atau lebih kreditor dan tidak membayar sedikitnya satu hutang yang telah jatuh tempo dan dapat ditagih dapat menjadi termohon pailit. ${ }^{8}$ Setiap debitor yang telah memenuhi syarat dimaksud dapat dipailitkan, baik debitor perorangan maupun badan usaha. Sebagaimana

\footnotetext{
${ }^{6}$ H.M.N. Purwosutjipto, Op., Cit, hlm 74.

${ }^{7}$ R. Soerjatin, Beberapa Soal Pokok Hukum Perdata Dan Hukum Dagang, (Jakarta: Pradnya Paramita) 1976, hlm 82.

${ }^{8}$ Aria Sayudi, Eryanto Nugroho dan Herni S, Op. Cit., hlm 93.
} 
telah dikamukakan diatas, badan usaha dapat berbentuk perseroan terbatas dan Persekutuan Komanditer.

Undang-Undang Kepailitan dan PKPU sendiri mengatur kepailitan terhadap badan usaha bukan badan hukum, dalam hal ini firma, pada pasal 5 yang berbunyi sebagai berikut:"permohonan pernyataan pailit terhadap suatu firma harus memuat nama dan tempat tinggal masing-masing persero yang secara tanggung renteng terikat untuk seluruh utang Firma".

Dengan berpedoman bahwa suatu persekutuan komanditer juga merupakan bentuk khusus persekutuan firma, maka dalam hal ini kita dapat menggunakan aturan pasal 5 undang-undang kepailitan dan PKPU dalam mengajukan permohonan kepailitan persekutuan komanditer, yakni dengan mengajukan permohonan pailit terhadap para sekutunya. Oleh karena dalam persekutuan komanditer terdapat pengurus/sekutu komanditer, maka yang kemudian yang menjadi suatu pertanyaan adalah apakah Persekutuan Komanditer dan semua sekutunya dapat ditarik menjadi termohon pailit jika pihak ketiga bermaksud mengajukan permohonan pailit terhadap persekutuan komanditer yang tidak mampu melunasi hutangnya yang telah jatuh tempo dan dapat ditagih.

Persekutuan Komanditer yang telah dinyatakan pailit oleh putusan Pengadilan Niaga, yang bertanggungjawab secara hukum adalah sekutu komplementer, sebab jika di lihat dari sudut pandang normatif hukum sekutu inilah yang mempunyai kewajiban untuk melunasi semua hutangnya. Sedangkan Sekutu Komanditer hanya bertanggungjawab kepada sekutu komplementer dengan menyerahkan sejumlah pemasukan, hal ini tentu sebagaimana yang dimaksud oleh Kitab Undang-Undang Hukum Dagang tentang Persekutuan Komanditer .

Dalam hal ini terdapat suatu putusan pada Pengadilan Niaga Medan Nomor.07/Pdt.Sus-Pailit/2015 yang mengabulkan permohonan pailit terhadap suatu Persekutuan Komanditer dimana yang turut dinyatakan berada dalam keadaan pailit selain sekutu komplementer juga terhadap sekutu komanditer. Dalam putusannya tersebut terlihat tidak adanya suatu pertimbangan dari majelis hakim dalam memberikan suatu klasifikasi mengenai tanggungjawab yang diemban oleh para pihak yang dinyatakan pailit dalam artian untuk membedakan antara sekutu komplementer dan sekutu komanditer.

Oleh karenanya beranjak dari putusan Pengadilan Niaga Medan tersebut peneliti berasumsi adanya suatu penerapan hukum yang perlu dikaji dan diteliti sebagai suatu permasalahan dalam penelitian. Maka dari itu peneliti bermaksud untuk menganalisis bentuk tanggung jawab yang dimiliki oleh setiap sekutu dalam perseroan komanditer ini 
khususnya dalam suatu proses kepailitan berdasarkan aturan yang berlaku, serta mengkaji makna dari putusan pailit bagi sekutu komanditer dalam suatu persekutuan komanditer dimana penelitian ini berpedoman kepada suatu putusan pengadilan yang telah berkekuatan hukum tetap.

\section{LANDASAN TEORI}

Kajian tanggung jawab sekutu komanditer pada badan usaha persekutuan komanditer dalam kepailitan, bagaimana kedudukan sekutu komanditer dalam persekutuan komanditer dan bagaimana akibat hukumnya jika sekutu komanditer ditetapkan sebagai debitor pailit dalam kepailitan persekutuan komediter.

\section{METODE PENELITIAN}

Metode pendekatan yang penulis lakukan ialah dengan jenis penelitian normatif atau penelitian hukum doktriner yaitu penelitian hukum yang mempergunakan sumber data sekunder ${ }^{9}$. Disebut penelitian hukum doktriner, karena penelitian ini dilakukan atau ditujukan hanya pada peraturan-peraturan yang tertulis atau bahan-bahan hukum lain. Serta juga dikatakan sebagai penelitian hukum perpustakaan atau studi dokumen disebabkan penelitian ini lebih banyak dilakukan terhadap data yang bersifat sekunder yang ada diperpustakaan. ${ }^{10}$

Penelitian ini mengutamakan data sekunder sebagai acuan utamanya yang di dapati oleh peneliti dari penelitian kepustakaan, dimana jenis-jenisnya dapat juga terlihat didalam daftar pustaka penelitian ini. Data utama dalam hal ini ialah Putusan Nomor: 07/Pdt.Sus-Pailit/2015/PN Niaga.Mdn.

Selain dari pada itu untuk menguatkan hasil penelitian ini penulis juga menyajikan data primer berupa hasil wawancara. Wawancara yang dilakukan oleh penulis adalah jenis wawancara bebas terpimpin yaitu jenis wawancara dimana pewawancara hanya membuat pokok-pokok masalah yang diteliti, dan selanjutnya dalam proses wawancara berlangsung, pewawancara mengikuti suasana interviewer tanpa kehilangan fokus/ menyimpang dari topik yang menjadi fokus penelitian dengan narasumber.

Penyajian Data yang digunakan dalam hal ini yaitu dengan cara memaparkan data sekunder berbentuk primer berupa kajian tanggung jawab sekutu komanditer dalam pelunasan hutang perusahaan berbentuk persekutuan komanditer melalui kepailitan.

\footnotetext{
${ }^{9}$ Ediwarman. Metodologi Penelitian Hukum. (Medan: PT Sofmedia), 2015. hlm 114.

${ }^{10}$ Suratman dan Philips Dillah. Metode Penelitian Hukum. (Bandung: Alfabeta), 2012, hlm 51.
} 
Sedangkan analisis data yang penulis gunakan ialah dengan dengan cara analisis kualitatif yang mengacu kepada peraturan perundang-undangan dan putusan pengadilan serta norma-norma yang hidup dan berkembang dalam masyarakat. ${ }^{11}$ Penulis dalam hal ini mengkonstantir fenomenologi yang terjadi dalam permasalahan dan duduk perkara pada penelitian ini.

\section{HASIL PENELITIAN}

Pemohon pailit adalah Supplier Tandan Buah Segar Kelapa (TBS) Sawit sedangkan termohon adalah pabrik kelapa sawit yaitu CV. Agro Sawita Perkasa, yang berkedudukan di Desa Pulo Dogom, Kecamatan Kualuh Hulu, Kabupaten Labuhan Batu Utara, Provinsi Sumatera Utara.

Pemohon pailit merupakan salah satu Supplier Tandan Buah Segar kalapa sawit kepada perusahaan termohon pailit dimana sejak desember tahun 2013 hingga bulan maret 2015 pemohon pailit senantiasa mengantarkan tandan buah segar nya kepada pihak termohon pailit, pemohon pailit bahkan mensuplai ribuan ton tandan buah segar dihampir setiap bulannya ke pabrik pengolahan yang dimikili oleh termohon pailit.

Sistem pembayarn jual beli tandan buah segar ini ialah dengan ketentuan setiap tandan buah segar (TBS) masuk akan dibayar sesuai dengan jumlahnya, yaitu harga TBS akan melihat ketentuan harga satuan Kilogram yang ditentukan oleh perusahaan termohon pailit atau berdasarkan ketentuan harga dari pemerintah. Namun seiring waktu berjalan, kerja sama bisnis antar pemohon pailit dan termohon pailit ini tidak berjalan dengan lancar adapun kendalanya ialah dalam hal pembayaran uang hasil penjualan TBS tersebut yang oleh termohon pailit tidak dibayarkan dengan alasan uang yang terlambat masuk.

Oleh karena itu dalam hal untuk mengantisipasi keterlambatan pembayaran uang ditakuti oleh pemohon pailit akan terjadi lagi dikemudian hari maka, pemohon pailit mengajak termohon pailit untuk membuat suatu perjanjian tentang sistem pembayaran TBS tersebut. Adapun perjanjian tersebut dibuat dihadapan Tresna Hariadi, SH, M.Kn Notaris di Aek Kanopan, yang isinya antara lain menerangkan:

1) Bahwa Pihak Pertama / Termohon Pailit I ada memiliki hutang atas pembelian Tandan Buah Segar sejak tanggal 31 Desember 2013 sebesar Rp. 2.856.393.210,- (

\footnotetext{
${ }^{11}$ Zainuddin Ali, Metode Penelitian Hukum, (Jakarta: Sinar Grafika), 2014, hlm 105.
} 
Dua milyar delapan ratus lima puluh enam juta tiga ratus sembilan puluh tiga ribu dua ratus sepuluh rupiah ) dari pihak Kedua / Pemohon Pailit.

2) Bahwa hutang tersebut akan dicicil oleh Pihak Pertama / Termohon Pailit I kepada Pihak Kedua/ Pemohon Pailit untuk pertama kali pada tanggal 28 Mei 2014 sebesar Rp. 356.393.210,- ( Tiga ratus lima puluh enam juta tiga ratus sembilan puluh tiga ribu dua ratus sepuluh rupiah ) Sisanya sebesar Rp. 2.500.000.000,- (Dua milyar lima ratus juta rupiah) akan dicicil oleh Pihak Pertama / Termohon Pailit I paling lambat 6 bulan sejak tanggal perjanjian ini ditanda tangani.

3) Bahwa selama hutang tersebut belum terbayar, maka Pihak Pertama / Termohon Pailit I dibebankan untuk membayar fee kepada Pemohon Pailit / Pihak Kedua sebesar $5 \%$ untuk setiap bulannya dihitung dari sisa hutang yang belum dibayar, adapun pembayaran fee tersebut akan dimulai sejak tanggal 24 Juni 2014.

4) Selanjutnya jika Pihak Pertama / Termohon Pailit I terlambat membayar fee setiap tanggal 24 pada tiap-tiap bulan berjalan, maka Pihak Pertama / Termohon Pailit I akan dikenakan denda sebesar Rp. 4.100.000,- ( Empat juta seratus ribu rupiah ) untuk setiap harinya tanpa mengurangi kewajiban Pihak Pertama/ Termohon Pailit I untuk membayar fee setiap bulannya.

5) Apabila tanggal jatuh tempo pada hari minggu / hari libur nasional, maka pembayaran denda fee tidak dikenakan, akan tetapi setelah hari kerja Pihak Pertama/ Termohon Pailit I tidak juga membayar denda fee, maka yang hari Minggu/ hari libur nasional tersebut tetap dikenakan denda dan harus dibayar oleh Pihak Pertama / Termohon Pailit

Setalah perjanjian ini dibuat dan kemudian kedua pihak sepakat untuk melaksanakannya, serta kagiatan bisnis antar mereka terus berlajan dengan biasanya. Namun seiring beiring berjalannya waktu dalam rentang antara tahun 2014 hingga bulan april 2015 ternyata banyak kesalahan-kesalahan yang dilakukan oleh pihak termohon piailit yang artinya bahwa ketentuan perjanjian Notaris tersebut akan berlaku untuk setiap pelanggagaran yang dilakukan yaitu berupa denda dan fee.

Bahwa terhadap keseluruhan utang termohon pailit tersebut, baik utang pada saat jatuh tempo, utang pembayaran fee dan denda perharinya berdasarkan perjanjian yang tersebut ialah berjumlah Rp. 5.484.000.000,- (lima Milyar empat ratus delapan puluh empat juta rupiah). Dalam hal ini sebenarnya pemohon pailit telah berualang kali menegur dan menagihnya kepada termohon pailit, namun termohon pailit tetap saja tidak membayar hutang tersebut. 
Perincan dari seluruh hutang termohon pailit ialah sebagai berikut:

1) Utang pada saat jatuh tempo sebesar Rp. 2.500.000.000,

2) Utang pembayaran fee selama delapan bulan Rp. 1.000.000.000,

3) Denda perhari sejak tanggal 25 November 2014 sampai dengan permohonan didaftarkan tanggal 06 Juli 2015 sebesar Rp. 984.000.000,

4) Penambahan utang setelah jatuh tempo sebesar Rp. 1.000.000.000,

Dalam menjalankan aktifitas bisnisnya ternyata termohon pailit salaku Direktur CV. Agro Sawita Perkasa juga memiliki hutang kepada kreditur lainnya yaitu, kepada Syarifuddin Simangunsong beralamat di Dusun V Sumber Sari, Kelurahan Sumber Harapan, Kecamatan Tinggi Raja Kabupaten Asahan Provinsi Sumatera Utara sebesar Rp. 251.325.850, (dua ratus lima puluh satu juta tiga ratus dua puluh lima ribu delapan ratus lima puluh). Utang tersebut merupakan sisa pembayaran TBS yang belum dibayarkan oleh teemohon Pailit kepada Syarifuddin Mangunsong.

Oleh karena adanya suatu pelanggaran berupa tidak dibayarnya hutang dan didukung oleh beberapa bukti yang dimilikinya, termohon pailit berniat untuk mengajukan suatu permohonan pailit kepada termohon pailit agar hak nya berupa hutang, denda dan lain sebagainya tersebut bisa didapatinya. Pemohon pailit berdasarkan fakta yang dikemukakannya memohon kepada hakim untuk memutus perkara dengan putusan sebagai berikut:

1) Menerima dan mengabulkan Permohonan yang dimohonkan oleh Pemohon Pailit untuk seluruhnya.

2) Menyatakan Pemohon Pailit adalah Kreditur Termohon Pailit I,II dan III yang sah menurut hukum.

3) Menyatakan Termohon Pailit I,II dan III, masing-masing bertindak sebagai Direktur, Wakil Direktur dan Pesero Perseroan Komanditer CV. Agro Sawita Mandiri Perkasa, berkedudukan di Desa Pulo Dogom. Kecamatan Kualuh Hulu, Kabupaten Labuhan Batu Utara, Propinsi Sumatera Utara Dinyatakan Pailit dengan segala akibat hukumnya.

4) Menunjuk dan Mengangkat Hakim Pengawas untuk melakukan pengawasan terhadap pengurusan dan pemberesan harta pailit tersebut.

5) Memerintahkan penyitaan segera atas seluruh harta kekayaan milik Termohon Pailit I,II dan III untuk selanjutnya dijual dan hasil penjualannya dipakai untuk pembayaran utang Termohon Pailit I,II dan III kepada Pemohon Pailit dan Kreditur lainnya. 
6) Membebankan seluruh biaya yang timbul dalam Permohonan ini kepada Termohon Pailit I,II dan III.

Atau apabila Bapak/ Ibu Majelis Hakim yang memeriksa Permohonan ini berpendapat lain, bersama ini Pemohon Pailit mohonkan putusan yang seadil-adilnya. ( Ex Aequo Et Bono ).

Commanditaire Vannnotschap atau CV sejatinya merupakan badan usaha yang berasal dar firma, namun memiliki perbedaan karena dalam hal jenis perseronya dimana firma hanya ada satu jenis persero yaitu sebagai pengurus secara keseluruhan sedangkan didalam Persekutuan Komanditer terdapat persero pengurus atau sekutu aktif dan persero komanditer atau sekutu pasif atau sekutu komenditer.

Sekutu komanditer dalam hal ini secara normatif berdasarkan pasal 19 KUHD merupakan sekutu atau persero yang hanya sebagai pelepas uang atau hanya memasukkan inbrengnya kedalam badan usaha Persekutuan Komanditer tanpa turut ikut campur menjalankan dan mengurus jalannya usaha perusahaan, dalam artian bahwa adanya batas dan peberbedaan antara sekutu komanditer ini dengan sekutu pengurus atau sekutu komplementer dalam Persekutuan Komanditer. Secara tanggungjawab pun juga demikian persero komanditer memiliki tanggungjawab yang terbatas dalam hal terjadi kerugian yang dialami Persekutuan Komanditer kepada pihak ketiga.

Menurut M. Yahya Harahap, status seorang sekutu komanditer dapat disamakan dengan seorang yang meminjamkan atau menanamkan modalnya pada suatu perusahaan. Yang diharapkan dari penanaman modal itu ialah hasil keuntungan dari modal yang ditanamkannya. Sekutu komanditer sama sekali tidak ikut terlibat mencampuri pengurusan dan pengelolaan persekutuan komanditer, seolah-olah dia tidak berbeda dengan pelepas uang. ${ }^{12}$

Dapat dipahami bahwa kedudukan sekutu komanditer didalam badan usaha Persekutuan Komanditer ini hanyalah sebagai seorang yang memberikan modal tanpa ikut mengurus perusahaan secara internanya dengan kata lain sebagai pelepas uang saja dan ia bukanlah wakil dari persekutuan komanditer tersebut di muka pengadilan jika ada pihak lain yang menggugat atau menuntut suatu hak kepada persekutuan komanditer tersebut. Dengan kedudukannya ini maka secara tidak langsung sekutu komanditer akan memiliki tanggungjawab yang berbeda pula dari sekutu pengurus terhadap kerugian yang alami Persekutuan Komanditer.

\footnotetext{
${ }^{12}$ M. Yahya Harahap, Op., Cit, hlm 17.
} 
Karena didalam Persekutuan Komanditer ada dua jenis sekutu yaitu sekutu pengurus dan sekutu komanditer mengakibatkan terdapatnya dua jenis tanggungjawab pula, yaitu tanggungjawab tidak terbatas dan (unlimited liability) dan tanggungjawab terbatas (limited liability. Tanggungjawab tidak terbatas atau pribadi (personal liability) artinya bahwa kreditor dapat menuntut kewajiban persekutuan tidak saja dari asset persekutuan tetapi juga dari asset pribadi para sekutu. Dengan kata lain, kontribusi sekutu pengurus termasuk pula memberikan jaminan atas kewajiban perusahaan, sedangkan tanggungjwab terbatas bermakna bahwa tanggungjawab pemilik atas utang perusahaan hanya sebesar modal yang ditanamkan dalam perusahaan. Resiko pemilik tidak lebih dari uang yang telah dibayarkan atau yang telah disanggupi sebagai bagiannya. Pemilik dengan tanggungjawab terbatas dapat dituntut hanya memenuhi janji yang telah disepakatinya.

Selanjutnya berdasarkan konsep bahwa fungsi sekutu pelepas uang adalah berbeda dengan fungsi kreditor karena sebagai pelepas uang. Sekutu komanditer sejak awal telah mengatahui resiko yang dihadapinya, yaitu perusahaan mengalami kerugian maka sekutu pelepas uang tidak dapat menuntut penggantian kepada sekutu lainnya yaitu sekutu komplementer. ${ }^{13}$ Hal ini sangat penting demi keberlangsungan usaha Persekutuan Komanditer terutama terkait kepengurusan internal Persekutuan Komanditer tersebut.

Pasal 5 dan 54 Kepailitan dan PKPU hanya mengatur tentang tata cara yang dilakukan untuk mengajukan permohonan pailit terhadap Firma yaitu dengan menarik seluruh persero yang secara tanggung renteng terikat untuk seluruh utang firma sebagai debitor pailit. Sedangkan Pasal 54 Kepailitan dan PKPU hanya menyinggung tentang hak sekutu yang terikat dalam persekutuan yang dibubarkan setelah dinyatkan pailit. ${ }^{14}$

Akibat hukumnya bagi sekutu komanditer bahwa ia ikut bertanggungjawab sama seperti sekutu komplementer sepanjang dapat dibuktikan adanya keikutsertaan sekutu komanditer tersebut untuk kepengurusan dan bahkan yang mengakibatkan kerugian perusahaan. Putusan pailit yang di berikan kepada Persekutuan Komanditer dan para sekutunya tersebut adalah bersifat konstitutif artinya bahwa sesuai dengan makna pailit tersebut mengakibatkan hilangnya hak dan kewajiban para sekutu dalam bertindak dalam lapangan harta kekayaannya dan beralih kepada kurator. Bagi sekutu komplementer sampai menyentuh harta pribadinya jika aset perusahaan tidak cukup untuk membayar

\footnotetext{
${ }^{13}$ Yetty Komala Sari, Loc., Cit, hlm 157.

${ }^{14}$ Elyta Ras Ginting, Op., Cit, hlm 151.
} 
hutang tersebut sedangkan bagi sekutu komanditer hanya sebatas inbreng yang dia berikan.

Berdasarkan Pasal 20 ayat 3 Kitab Undang-Undang Hukum Dagang maka putusan pengadilan niaga medan tersbut dapat dinilai kurang tepat, hal ini karena Pasal 20 ayat 3 tersebut menjelaskan bahwa sekutu komanditer tidak dibenarkan untuk memikul kerugian lebih dari jumlah uang telah dimasukkannya kedalam perusahaan. Hal ini juga didukung oleh pendapat para sarja yaitu:

Prof. Dr. Faisal Santiago yang menyatakan bahwa sekutu sekutu pasif atau komanditer sesungguhnya tidak bisa dipailitkan karena tanggungjawab tersebut seharusnya diemban oleh sekutu aktif/ komplementer karena sekutu pasif hanya berkewajiban memberikan pemasukan sesuai yang telah disepakati bersama. Senada dengan hal tersebut Dr. FX Arsin Luxman mengatakan bahwa adalah suatu ketidakwajaran jika sekutu komanditer ikut dilibatkan dalam kepailitan persekutuan komanditer, hal ini karena ia hanya bertanggungjawab sebatas modal yang diserahkannya saja.

Penjelasan yang sedikit berbeda disampaikan oleh Dr. Hotman Paris Hutapea, yang mengatakan bahwa apakah sekutu komanditer/ pasif menjadi sekutu komplementer/ pasif bila ikut melakukan pengurusan perusahaan adalah tergantung anggaran dasar persekutuan komanditer tersebut. Secara logika hukum hal itu bisa saja terjadi, tandas beliau.

Menurut penulis pendapat para sarjana diatas kurang memberikan jawaban yang pasti terhadap tanggungjawab sekutu komenditer tersebut, karena jika mengacu kepada akta anggaran dasar pendiriannya yang dibuat oleh Notaris maka sejatinya juga notaris berpedoman kepada undang-undang yaitu Kitab Undang-undang Hukum Perdata dan Kitan Undang-Undang Hukum Dagang, oleh karenanya menurut penulis belum adanya penegasan dan solusi yang kuat dari pendapat para sarjana tersebut diatas.

Sedangkan pendangan yang berbeda terhadap putusan Pengadilan Niaga medan ini disampaikan oleh Prof. Dr. I Ketut Oka Setiawan yang manyatakan bahwa sekutu komanditer dapat dimintai pertanggungjawaban atas kerugian yang dialami persekutuan komanditer jika terbukti terlibat dalam melakukan pengurusan perusahaan tanpapun hal itu tercantum dalam anggaran dasar persekutuan komenditer tersebut karna keikutsertaan sekutu komanditer dalam pengurusan perusahaan telah menandai bahwa ia sepakat memikul tanggung jawab yang sama dengan sekutu komplementer. Hal ini juga di amini olah Dr. Yoyo Arifardhani beliau mengatakan jika ternyata sekutu pasif ikut dalam 
melakukan usaha persekutuan komanditer dan juga ikut menikmati hutang perusahaan maka sekutu komanditer dapat juga dimintai pertanggungjawaban layaknya sekutu komplemnter.

Pandangan sarjana yang kedua ini menurut penulis lebih tepat karna dengan tegas menjelaskan bahwa tanggung jawab sekutu komanditer tersebut dapat berubah dan ia juga harus bertanggungjawab atas segala kerugian perusahaan yang jika ia terlibat didalamnya, oleh karenanya penulis mengganggap jawaban yang tepat untuk bentuk pertangungjawaban sekutu komanditer dalam kepailitan ialah pandangan yang kedua ini.

Hakim yang dalam putusannya menetapkan sekutu komanditer sebagai debitor pailit dinilai kurang tepat, karna kedudukan sekutu komanditer dalam persekutuan komanditer hanya sebagai pelepas uang dan tidak bisa mewakili perusahan untuk bertindak keluar dan tanggu jawabnya pun berbeda dengan sekutu komplementer yaitu hanya sebatas pemasukannya saja.

\section{KESIMPULAN}

Berdasarkan hasil pembahasan tesis ini sesuai dengan topic permasalahan yang peneliti utarakan, maka peneliti menyusun beberapa hal yang merupakan kesimpulan dari penelitian ini, yaitu:

1. Sekutu Komanditer dalam sebuah badan usaha berbentuk Persekutuan Komanditer memiliki kedudukan sebagai pihak pelepas uang dan tidak bisa menjadi wakil perseoran dalam hal apapun untuk bertindak atas nama perseroan karna hal itu merupakan kewenangan dan tugas sekutu komplementer. Kewajibannya terhadap Persekutuan Komanditer ialah memberikan pemasukan modal berupa uang, sedangkan hak nya ialah berhak menerima laba dari hasil usaha yang dijalankan perusahaan secara proporsional sebesar pemasukan yang dia berikan.

2. Secara normatif sekutu komanditer tidak dapat dinyatakan sebagai pihak yang ikut bertanggungjawab dalam kepailitan persekutuan komanditer. Kerena ia hanya bertanggung jawab sebesar pemasukannya. Tanggungjawabnya akan berubah apabila ia terbukti ikut melakukan pengurusan dan menyebabkan kerugian pada persekutuan komanditer.

Akibat hukumnya ialah tanggung jawab sekutu komanditer tersebut menjadi sama seperti sekutu komplementer yaitu bertanggungjawab penuh hingga ke harta pribadinya. Namun, Putusan Pengadilan Niaga Medan Nomor 07 Tahun 2015 dinilai kurang tepat dan bertentangan dengan ketentuan Pasal 20 KUHD, dimana sekutu 
komanditer dinyatakan sebagai debitor pailit tanpa mempertimbangkan keterlibatannya dalam keadaan yang menyababkan terjadinya kepailitan tersebut.

\section{DAFTAR PUSTAKA}

\section{Buku}

Ali, Chidir, Badan Hukum, Bandung, Alumni, 1991.

Ali, Zainuddin, Metode Penelitian Hukum, Jakarta, Sinar Grafika, 2014.

Ediwarman, Monograf Metode Penelitian Hukum, Medan, PT.Sofmedia, 2015.

Ginting, Elyta Ras , Hukum Kepailitan Teori Kepailitan, Jakarta, Sinar Grafika, 2018.

Harahap, M. Yahya, Hukum Perseroan Terbatas, Jakarta, Sinar Grafika, 2011.

Purwosutjiopto, H.M.N, Pengertian Pokok Hukum Dagang Indonesia 2, Bentuk-Bentuk Perusahaan, Jakarta, Djambatan, 2007.

Sayudi, Aria, Eryanto Nugroho dan Herni S, Nurbayani, Analisis Hukum Kepailitan Indonesia, Kepailitan Dinegeri Pailit, Jakarta, PSHK, 2004.

Soerjatin, R, Beberapa Soal Pokok Hukum Perdata Dan Hukum Dagang, Jakarta, Pradnya Paramita, 1976.

Soekardono, R, Hukum Dagang Indonesia, Jakarta, Rajawali Press, 1981.

Suratman dan Philips Dillah, Metode Penelitian Hukum, Bandung, Alfabeta, 2012. 